研究ノート

\title{
ニジェール南部サヘル地域の耕作地におけ る農耕民ハウサの樹木に対する認識と利用
}

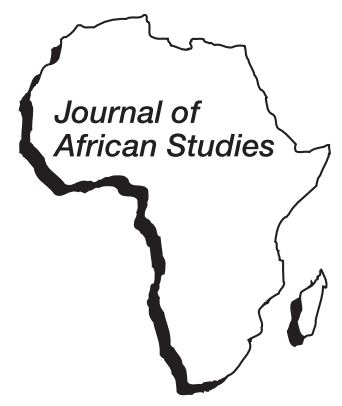

京都大学大学院アジア・アフリカ地域研究研究科 / 日本学術振興会特別研究員

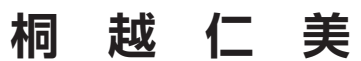

西アフリカのサヘル地域では, 人口増加や耕作地の拡大に起因した土地荒廃の問題が深刻化している。乾燥 や不安定な降雨, 貧栄養土壇などの厳しい状況のもとで, 農耕民八ウサは耕作地内に生育する樹木の形状を認 識し，その樹形を管理することによって，食料生産に活用している。

人びとは耕作地に生育する樹木の形状を，（1）樹齢 1 年以下で剪定されていないラブ，（2）樹齢 2 年以上で 剪定されていないバラウ，（3）樹高がトウジンビエより低く，下方の枝が剪定されたマタシ，（4）樹高がトウ ジンビエより高く，太い幹を有したマヤンチの 4 種類に分類している。

人びとは，ラブとバラウを表土の流亡の防止と土地荒廃への対策に利用し，マタシを風や太陽熱から作物を 保護する目的で利用していた。マヤンチは，木陰が休憩場所や牧畜民のキャンプに利用される一方で，樹木の 葉や実が食料や家畜の飼料として利用され，貴重な救荒食料の供給源となる。耕作地の保有者は，みずからの 食料状況や耕作地の状態と, 耕作地に生育する樹木をむすびつけて, 樹木の形状を管理し, 食料生産に樹木の 利用を積極的に取り入れていることが明らかとなった。

\section{はじめに}

西アフリカ, サハラ砂漠の南縁には, サヘル地域と 呼ばれる広大な地域が存在する。このサヘル地域では, 1970 年代と 1980 年代の大干ばつ以降, 土地の荒廃現象 である砂漠化が問題視されている（UNEP, 1992）。

砂漠化には植林が必要であるとして, 1970 年代以降, サヘル地域における植林技術に関する研究が数多くなさ れた（Weber et al., 1983; Molagnoux et al., 2007 など）。一 方で, サヘル地域では, 農耕民や牧畜民による土地荒廃 を防ぐための伝統的な資源管理の実践が確認されており (Berkes et al., 2000), 砂漠化の問題が注視され植林の必 要性が訴えられるようになる以前から, 人びとの在来知

2014 年 9 月 2 日受付, 2014 年 11 月 26 日受理 連絡先：干 606-8501 京都市左京区吉田下阿達町 46 京都大学大学院アジア・アフリカ地域研究研究科 e-mail: kirikoshi@jambo.africa.kyoto-u.ac.jp
識により生態系の維持が図られてきた。

サヘル地域では各地で森林法やプロジェクトにより植 生の維持・回復が試みられてきたが, 厳しい規則や労働 力の必要性から現地の人びとの生活を圧迫する事例も みられ，植生の保護には地域に根ざした資源管理方法 の改善が必要であることが指摘されている（Wezel and Lykke, 2006 など)。サヘル地域における土地荒廃の問題 とその対策を議論するためには，樹木に関する外来の知 識や管理技術だけではなく，人びとのもつ樹木に関する 在来の生態知識や樹木との関わりを明らかにすることが 必要であろうと考えられる。

本論文では，ニジェール南部において耕作地に生育す る樹木やその土地荒廃の防止の効果に関するハウサの人 びとの認識を検討し，それにしたがってどのように樹木 を利用，管理しているのかを明らかにする。 


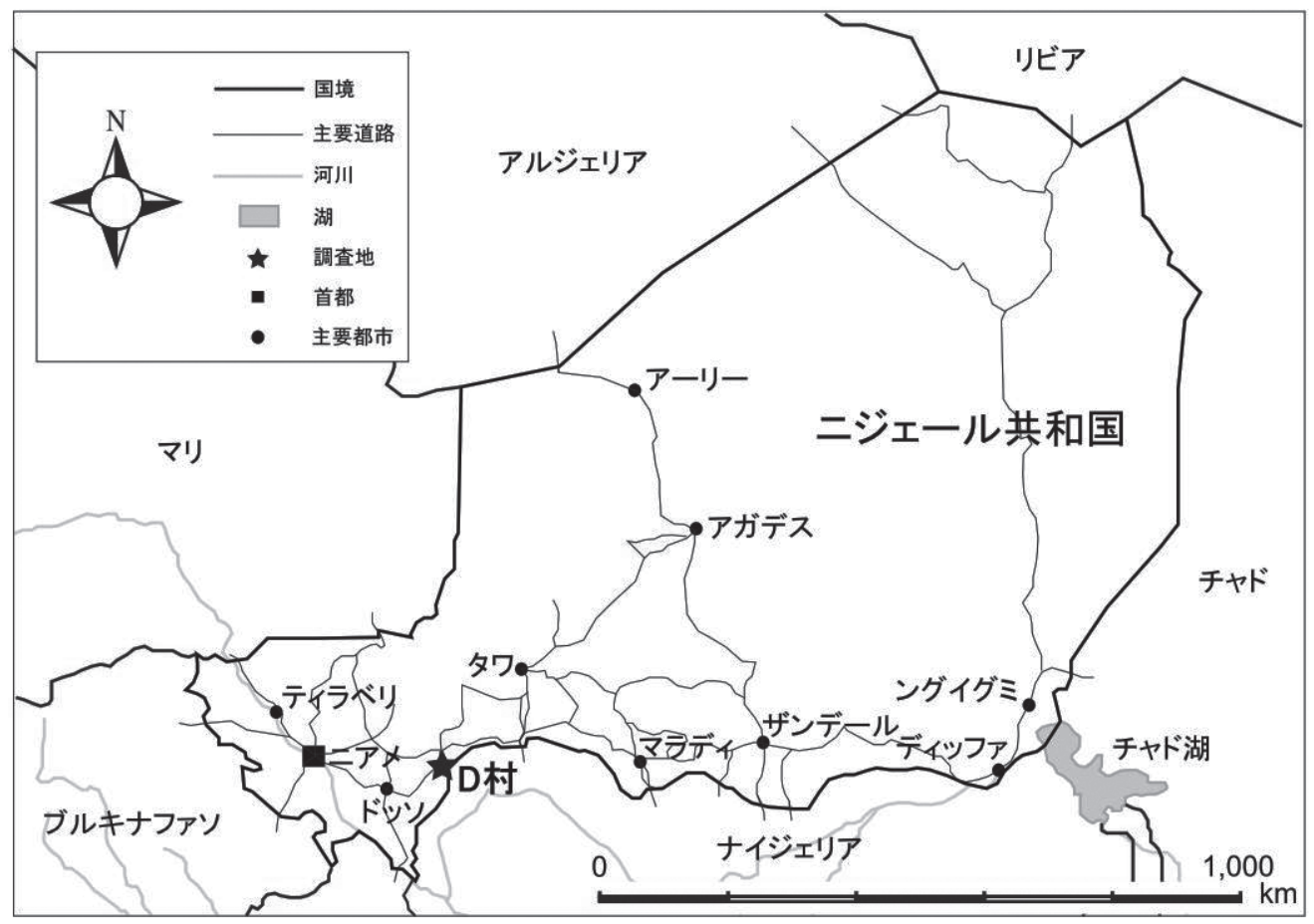

図1. 調査地

\section{1. 調査地概要}

\section{1. 気候, 地形, 土壌}

調査地は，西アフリカ・ニジェール共和国の首都ニア メより東方約 $250 \mathrm{~km}$ のドッソ州ドッチ県 D 村（図 1) である。D村を含むニジェールの南部は, サハラ砂漠の 南縁に広がるサヘル地域に位置する。雨季は 6 月から 9 月までの 4 ケ月間, 乾季は 10 月から 5 月までの 8 ケ月 間である。10月から 11 月，2月から 5 月には最高気温 が $35^{\circ} \mathrm{C}$ 以上の高温になり，時には $40^{\circ} \mathrm{C}$ 以上の猛暑とな る日も多い。

$\mathrm{D}$ 村の北西約 $7 \mathrm{~km}$ に位置する町，ドゴンドゥチでは, 1923 年から気象観測が継続されており，30 年間の平均 年降水量は $465 \mathrm{~mm}$ であった（Yearly amount data 2010, Direction de la Meteorologie Nationale du Niger)。

サヘル地域における砂漠化は，強風や降水による侵食 により, 表土が減少していくことによって生じる (Ikazaki et al., 2011)。調査村はインゼルベルグ（孤立残丘）の西 側に位置しており，インゼルベルグから村にかけては緩 やかに傾斜している。その斜面上部では土壤の堆積が薄 く,インゼルベルグ上の雨水が西に向かって流れる際に,
水食（シート浸食とリル浸食，およびガリー浸食）によ り土壤の流亡が生じている。東から吹き付ける強風によ る地表面の土畩層の風食も加わり, 植生の後退や土地荒 廃が東方から進行している。

ハウサの人びとは表層の状態で土壤を区分し，それと 土地荒廃の進行状態を関連づけ，土壤の肥沃度と作物生 産性の程度を判断する（Hayashi et al., 2000a; 大山, 2010 など）。調査村において住民は耕作地内の土壌の状態を， カサ (kasa), レソ (leso), フォコ (foko) の 3 種類で 表現する。カサは有機物を含む褐灰色の砂土が空隙の多 い状態で堆積した土壤である。レソは有機物をほとんど 含まない淡橙色の砂土であり，フォコは有機物をほとん ど含まない明赤褐色の砂土が緻密に堆積した土䁃であ る。カサは生産性のある土壤と認識され, 荒廃が進行す ると呼称がレソやフォコへと変化する。住民は経験上, レソを土地荒廃の初期段階と理解し，レソからカサへの 回復は比較的容易であるが, フォコまで荒廃が進行する とカサへの回復は難しいと認識している。

\section{2. 民族構成と世帯, 生業}

D 村は 2010 年現在, 60 世帯，390人が居住し，60 世 帯のうち 57 世帯が農耕民のハウサ，2 世帯が牧畜民の 


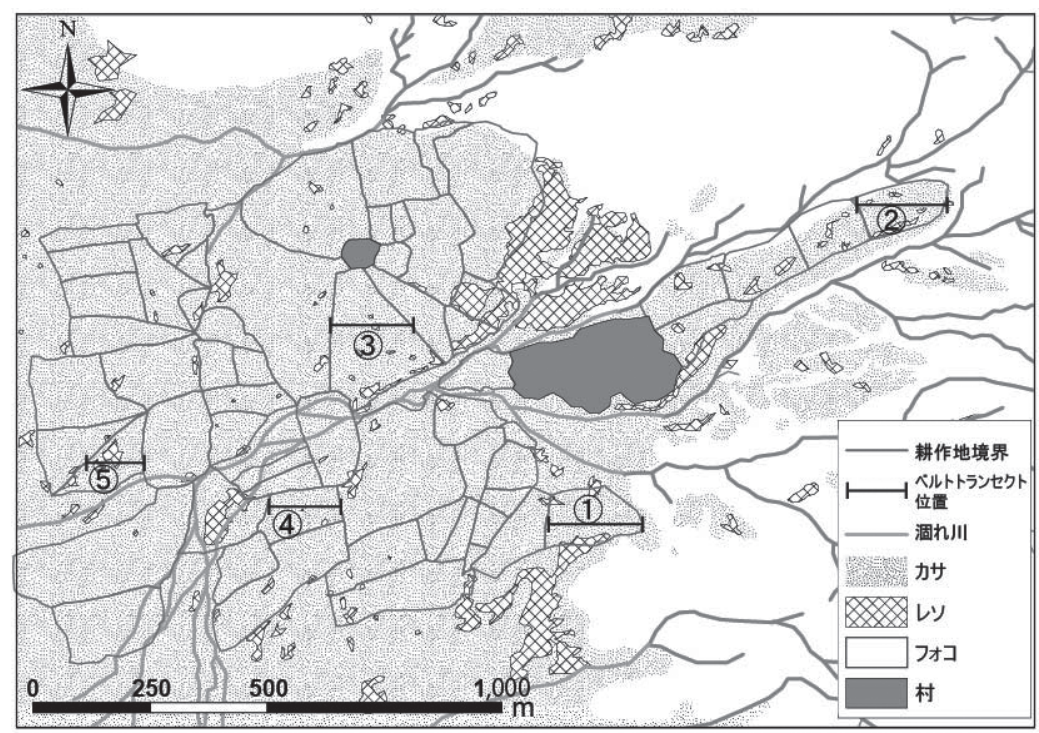

図 2. 調査村周辺におけるハウサの認識にもとづいた土䁃区分図と土地保有の境界線

(1)〜(5)については，調査したベルトトランセクトを示す)

フルベ，1世帯が牧畜民のトゥアレグであった。

調査地では，天水依存の農耕が営まれている。住民は 自給食料となるトウジンビエ (Pennisetum glaucum) と ササゲ (Vigna unguiculata) を栽培しており，雨季のは じまりにあたる 6 月にトウジンビエとササゲが播種さ れ， 7 月から 9 月までの 3 ケ月間にわたって 2 回の除草 作業がおこなわれる。雨季の終わる10月から作物が収 穫される。耕作期間中の雨季には, 前年に収穫された作 物の貯蔵が底をつく世帯が多くなり，この時期が食料の 欠乏する端境期にあたる。

\section{2. 調查方法}

筆者は 2010 年より 2013 年にかけて合計 8 ケ月間に わたって，D村に住み込みで調査を実施した。調査村 周辺の耕作地における地表面の状態を確認するため, World View2 高解像度衛星画像 (2011 年 11 月 20 日撮影, Digital Globe 社撮影, 解像度 $0.5 \mathrm{~m}$ ) とGPS を用いてグ ランド・トゥルースをおこない, 画像の色調を判読し, 住民のもつ土壤の表層の状態の区分にしたがって調査村 付近の土地を分類した（図 2)。住民の認識にもとづい た土壤区分図上で検討し, 東西方向に幅 $20 \mathrm{~m}$ の 5 本の ベルトトランセクト（トランセクト 1: $200 \mathrm{~m}$, トランセ クト 2: $232 \mathrm{~m}$, トランセクト 3: $208 \mathrm{~m}$, トランセクト 4: $146 \mathrm{~m}$ ，トランセクト 5: $122 \mathrm{~m}$ ）を設置した。これらの
ベルトトランセクトは，それぞれ 1 人の村人が保有する 耕作地の東端から西端を結ぶように設置した。ベルトト ランセクト上では，地表面の起伏や土畩の民族区分，樹 木の分布を調査した。

トランセクト 1 とトランセクト 2 は耕作地（カサ）と 荒廃地（フォコ,レソ）が接しており, 侵食を受けやすく, 土地が荒廃しやすい耕作地である。トランセクト 3 と卜 ランセクト 4 は除草作業をはじめとする農作業の手入れ が行き届いている耕作地である。トランセクト 5 は土地 の保有者が高龄女性のため，4年にわたって放棄された 休耕地である。

5 本のベルトトランセクト上では，ハンドレベルを用 いて地形断面の簡易測量をしたうえで，樹木の位置と樹 高，胸高直径，地表面から枝までの高さを測定した。ま た, 各樹木の種名と樹形, ベルトトランセクト上の土壤 の表層の状態についての民族区分については聞き取りを おこなった。聞き取りや樹木の調査，地形の測量などの 現地調査は, 村に居住する男性 4 人の協力のもとで実施 した。

\section{3. 樹形に関する住民の認識と樹木に期待す る効果}

住民は耕作地の樹木について, その葉や実を自分たち の食料や家畜の飼料に利用するほか, 土地荒廃を防止す 

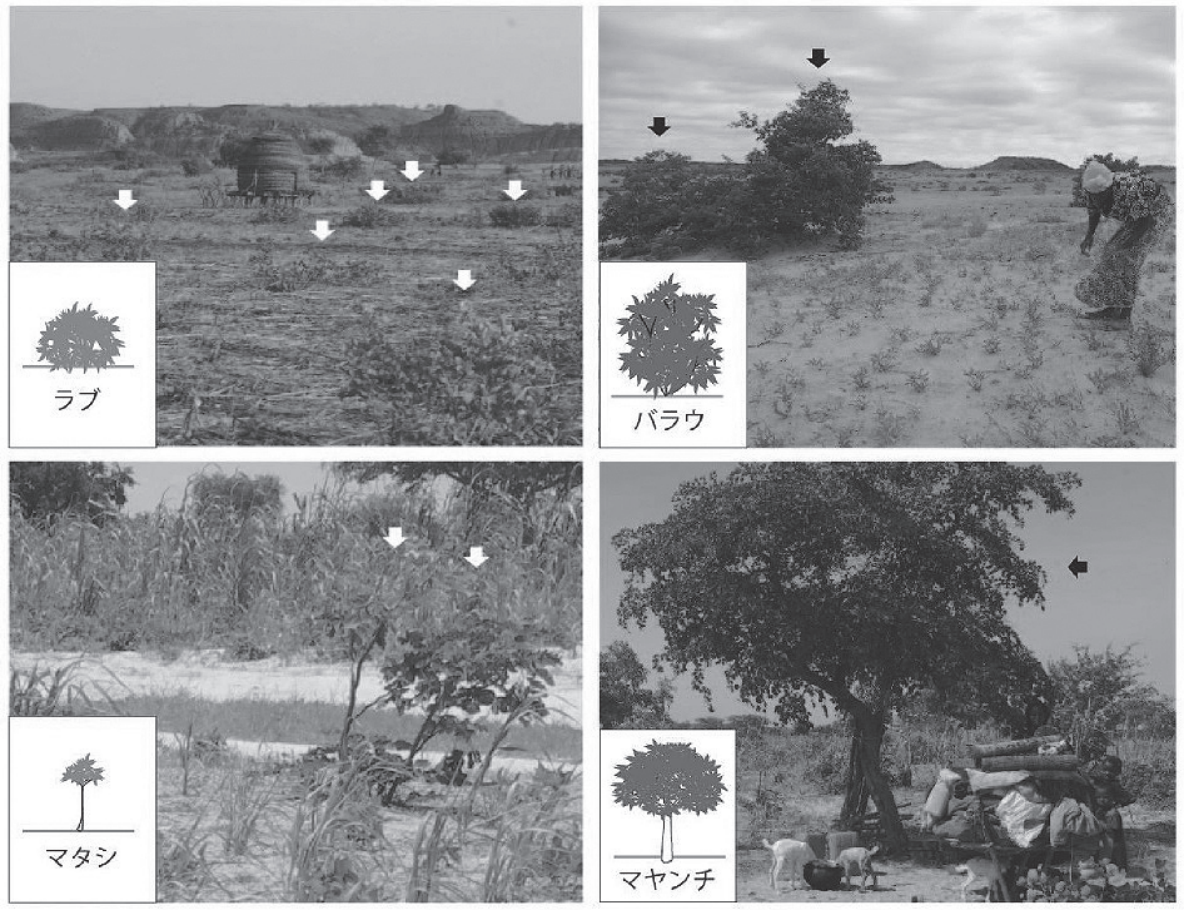

図 3. ハウサによる樹形の分類。樹齢 1 年以下で剪定されていない灌木のラブ (左上), 樹齢 2 年以上で剪定されていないバラウ (右上), 樹高がトウジンビエの株高より低く，下方の枝が剪 定されたマタシ (左下), トウジンビエの株高より樹高が高く, 太い幹を有したマヤンチ（右下）

るために利用している。住民は「耕作者の意図にあわせ て，樹木を適切な状態で残せば，樹木は耕作地の土壤を 改善する」と語り，樹種とともに樹形を重視している。 住民は樹形を目視によって 4 種類に分類し（図 3)，そ れぞれの樹形に対して耕作地における特定の効果を期待 している。

住民たちが語る 4 種類の樹形の名称とその特徴をまと めると，（1）樹齢 1 年以下で剪定されていない潅木のラ ブ (laubu)，（2）樹齢 2 年以上で剪定されていないバラ ウ (barau), (3) 樹高がトウジンビエの株高（約 $3 \mathrm{~m}$ ) より低く，下方の枝が剪定されたマタシ (matashi)，（4） トウジンビエの株高より樹高が高く，太い幹を有したマ ヤンチ (mayanchi) となる（図 3)。

ラブが生長するとバラウとなり， ラブまたはバラウの 下方の枝が剪定されるとマタシと呼ばれる。マタシを剪 定しつつ生長させるとマヤンチとなるが，そのまま放置 するとラブまたはバラウへと戻ってしまう。樹形の名称 は，樹木の生長，あるいは人びとの剪定によって変化す る。以下では, ベルトトランセクト上の樹木分布（図 4) から，住民による 4 種類の樹形の認識と樹木に期待して
いる効果について記述する。なお図 4 では, 侵食が東方 から進行しているという住民の認識にしたがい，各ベル トトランセクトの東端をそろえて表示した。

\section{1. ラブ}

ラブは地面を覆う小さな茂みをもつ潅木である。地下 茎や切り株からの萌芽や, 実生を起源とした樹齢 1 年以 下の樹木の形状を指す (図 3)。ハウサは毎年, 作物の 播種前, 2 月から 4 月の間に耕作地の灌木を伐採するが, その際，翌年には樹木が再生するように地下茥を残し， 地上部だけを切除する。ラブの樹木には, 地下茥からの 再生が速やかに生じる Guiera senegalensis や Piriostigma reticulatum などの樹種が多く，51 個体のラブのうち 40 個体が G. senegalensis, 8 個体がP. reticulatum であった。

ラブのもたらす効果について住民に聞き取りをおこな うと, 「一番期待している効果は, 風で飛ばされてきた 砂の捕捉と風雨による砂の流亡の防止だ」と話し, 飛砂 の捕捉効果が高いとされる。耕作地 (カサ) と荒廃地 (フォ コ，レソ）が接しているトランセクト 1 やトランセクト 2 では，侵食が生じやすい東端から $100 \mathrm{~m}$ の範囲に，1 
〜 $10 \mathrm{~m}$ おきに樹高 $0.5 \sim 1 \mathrm{~m}$ の G. senegalensis やP. reticulatum のラブの分布がみられた（図 4)。

また，住民は「ラブはトウジンビエの根元を 冷やすため, トウジンビエが大きく育つ」とも 語っており，無降雨の期間が続いた際の地温の 上昇を抑制する効果をラブに期待している。樹 木の管理が行き届いていると評価される耕作地 のトランセクト 3 では, 無降雨期間への対処と して $80 \mathrm{~m}$ 地点と $190 \mathrm{~m}$ 地点に樹高 $0.5 \mathrm{~m}$ 程度の P. reticulatum のラブが意眓的に残されていた。

\section{2. バラウ}

バラウは 2 年以上にわたって手入れが放置さ れた樹木であり，ラブよりも大きな茂みをつく る（図 3)。耕作地内では，荒廃した土地でも生 育可能で, 生長が速く大きな茂みを形成しやす いG. senegalensis のバラウが多く生育していた。

バラウのもつ飛砂の捕捉効果や強風から作物 を保護する効果は大きいとされ，耕作地（カサ） と荒廃地（フォコ，レソ）の境界付近に位置す るトランセクト 1 とトランセクト 2 では，意図 的に荒廃地の拡大防止にバラウの樹木が利用 されていた。トランセクト 1 上では 150 〜 180 $\mathrm{m}$ の範囲で樹高 $3 \sim 5 \mathrm{~m}$ の G. senegalensis と Borassus aethiopium のバラウが確認され, トラ ンセクト 2 上では $0 \sim 70 \mathrm{~m}$ の範囲で樹高 $2 \sim 3$ $\mathrm{m}$ の G. senegalensis と Ziziphus mauritania のバラ ウが確認された。

サヘル地域ではサバクバッタの虫害による, 作物の収量の大幅な減少が報告されている（石 本, 2012)。ラブやバラウの地面を覆う茂みにつ いて，住民は「サバクバッタの家（gidan fara）」 と表現し，ラブやバラウを耕作地に必要以上に 残すことは，サバクバッタの増加につながると 考えている。そのため, ラブやバラウは時に耕 作者の勤勉さの判断基準にも使われる。耕作放 棄中のトランセクト 5 では, ラブの樹木が 16 個 体, バラウの樹木が 5 個体とほかに比べて多く, 住民はこのような耕作地に対して「この耕作地 はラブやバラウばかりで，農作業を怠っている」 と評価する。なお，手入れがなされているトラ ンセクト 3 とトランセクト 4 では, バラウは確 認されなかった。

\section{3. マタシ}

マタシは，地面を覆う茂みをつくらないよう

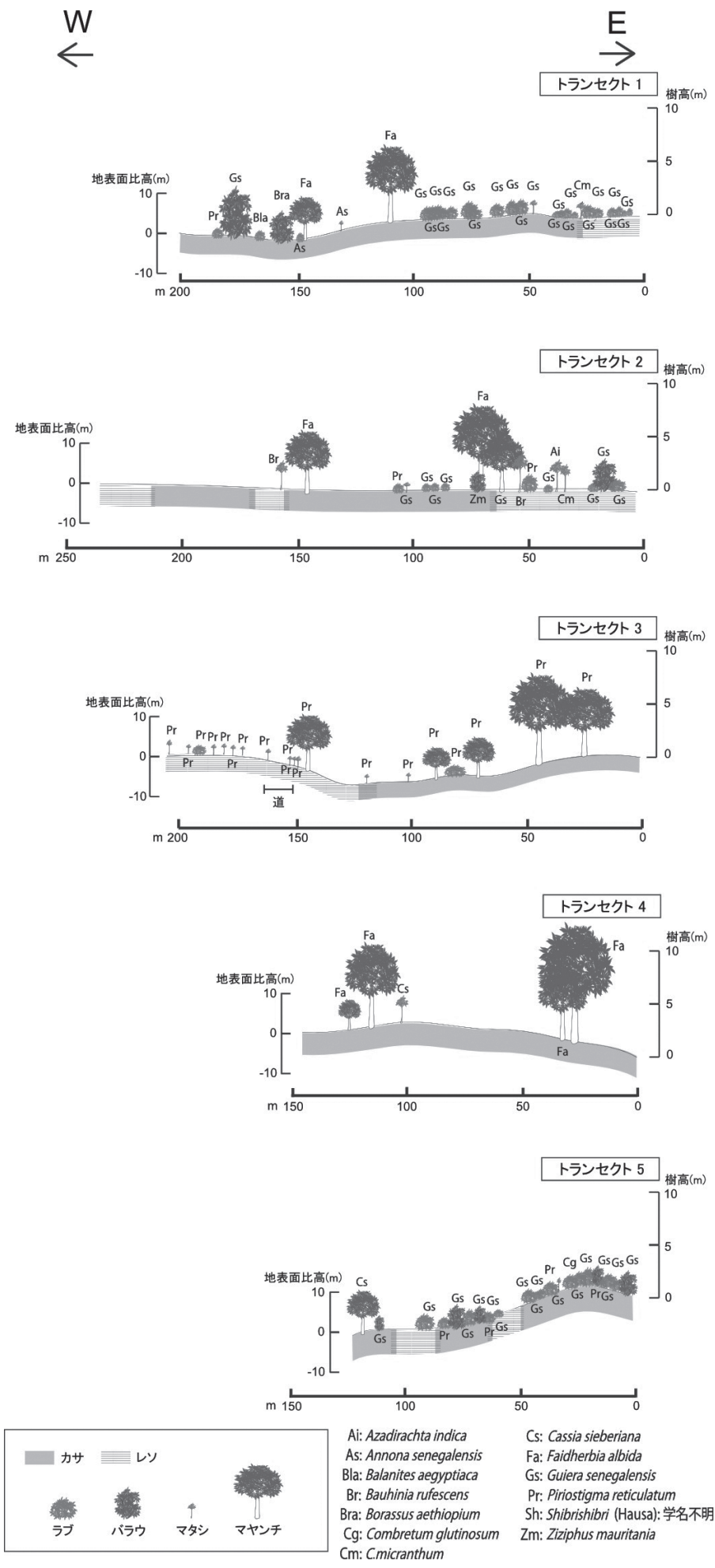

図 4. 5 筆の耕作地におけるべルトトランセクト上の樹木分布。 土壤の分布は土壤の表層の状態をあらわす。 
に下方の枝を切り落とした小さな樹木である。次節で説 明するマヤンチという大きな樹木への生長途中の樹形と して認識されている（図3）。

トランセクト 4 の $100 \mathrm{~m}$ 地点で確認されたマタシは, 耕作地の保有者によると, マヤンチへと生長させている 途中であった。トランセクト 3 上では, 地下茎からの再 生, 生長が速いP. reticulatum の枝が剪定され, マタシ の樹形をもつ 12 個体が確認された。

マタシには多くの効果は期待されていないが，住民は 剪定を加えマタシに仕立てることによって, サバクバッ 夕の住処となる茂みをなくすとともに, 強風や地温の上 昇からトウジンビエを守ることができると認識してい る。土地荒廃の初期段階であるレソの土地では作物が強 風や地温の上昇の影響を受けやすく, トランセクト $2(0$ 〜 $70 \mathrm{~m})$ やトランセクト $3(120 \sim 208 \mathrm{~m})$ 上のレソでは 作物の保護のためにマタシが残されていた。

\section{4. マヤンチ}

マヤンチはトウジンビエの株高よりも樹高が高く，太 い1 本の幹からなる樹木である（図 3)。トランセクト 5 上では, Cassia sieberiana が大きな葉をつけ, 強い日 差しを避けるための休㮩場所として利用されていた。荒 廃が進行していないトランセクト 4 では休㮩場所となる Faidherbia albida のマヤンチと生長途中の C. sieberiana のマタシのみがみられた。

マヤンチの大きな樹木は, 八ウサの人びとが牧畜民に 依頼する野営契約に必要である。野営契約とは, 農耕民 と牧畜民との間で交わされるもので, 農耕民が耕作地内 に牧畜民の放牧キャンプを誘致し, キャンプの周囲に家 畜粪が供給されることで耕作地の土壤の改善に役立つと される（大山ほか，2011）。牧畜民は, 放牧キャンプを 大きな木陰の近くに設営するため, 滞在する耕作地内に マヤンチがあることを野営契約の条件とする。トランセ クト 1 からトランセクト 4 までの耕作地には樹高 $5 \mathrm{~m}$ 以 上のマヤンチが残されており, 野営契約のための条件を 満たしていた。

マヤンチの樹木の葉や実は, 女性が救荒食料や家畜用 の飼料として利用し, 時にそれらを市場で販売して不足 する食料を補うために必要である。しかし住民は, マヤ ンチが作物の生長に必要な日光を遮蔽し, 作物の生産量 の減少を招く危険性があると認識している。耕作地の保 有者はトウジンビエを栽培する面積を確保しつつ, 生育 する樹木の有用性を考慮に入れて, マヤンチの生育密 度を調整する必要がある。トランセクト 2 からトラン セクト 4 の耕作地では, 樹高 $5 \mathrm{~m}$ 以上の F. albida や P. reticulatum のマヤンチが扮扮よそ $100 \mathrm{~m}$ の間隔で分布し
ており,長い乾季のあいだ, 葉や実が村の女性たちによっ て採取されていた。

\section{4. 耕作地における樹木管理についての評価 と今後の課題}

耕作地内に成立する樹林は, アフリカのサバンナ地域 では広くみられ (平井, 2009; 藤岡, 2010), 耕作地内の 有用樹の選定とその育成方法に関する議論が㧍こなわれ てきた（Pearce, 1988; Bielders et al., 2002）。本論文では, 住民が 4 種類の樹形を使い分け，それぞれの樹形に特定 の効果を期待していることが明らかとなった。

耕作地の土壤侵食の抑制や飛砂の捕捉効果を期待する 場合には，ラブやバラウといった樹形が必要となる。乾 季の 12 月から 2 月にかけて, 調査地では北東から砂塵 を多く含んだルルッタンが吹き付け, 運搬された砂塵 はラブやバラウの茂みにより捕捉される。乾季にはラブ やバラウの樹木下に砂塵の堆積が観察されており, 飛砂 の捕捉の点に抢いて住民の意図通りに樹木が機能してい ると予想される。

マヤンチの存在には, 牧畜民との野営契約による家畜 粪の供給が期待されており, 実際に一度の野営契約期間 中に $0.6 \sim 2 \mathrm{~kg} / \mathrm{m}^{2}$ の家畜䨢の供給が確認された。また, マヤンチの樹木の葉や実から救荒食料の確保や家畜飼料 の入手が可能となる。女性による耕作地からの樹木の葉 の年間採取料は, 救荒食料となる Balanites aegyptiaca は $5 \sim 35 \mathrm{~kg}$, 飼料となるF. albida は $20 \sim 150 \mathrm{~kg}$ であり, それぞれ生計維持のために利用されていた。

耕作地における樹木の生育は様々な効果が期待される 一方で, 作物の生長を妨げる可能性があるとされている。 マヤンチに育てたい樹木について, 剪定を施しマタシに 仕立てることで作物栽培への妨害を防ぐ必要がある。マ ヤンチの育成は, セネガルのセレール社会におけるアル ビダ (F. albida) のしつけ (平井, 2009) と同様の樹木 管理の手法であるといえる。樹種によっては 2,3 週間に 一度の剪定を必要とするが, 住民はマヤンチの存在によ り得られる効果を期待し, 将来への先行投資として耕作 地に扔いてマタシを育てている。

サヘル地域では, 土地荒廃や干ばつが発生する一方で, 人口は急増し, 耕作地も狭小化しているのが現状である。 こういった厳しい環境を生き抜くために，住民は積極的 に樹木を耕作地内に残していると考えられるが，土地荒 廃の問題と樹木管理による対策を議論するためには, こ れらの効果について定量的なデー夕による検証が必要で ある。住民による樹木管理の効果の検証については, 今 後の課題としたい。 


\section{謝辞}

本研究は, 旭硝子財団第 1 回環境研究 近藤次郎グラ ント「西アフリカ・サヘル地域における都市と農村の物 質循環の構築一都市の生ゴミ施用による農村における荒 廃劣悪地の修復に関する科学的検証（大山修一京都大学 准教授), 平成 22 年度環境省環境研究総合推進費「地域 住民の REDDへのインセンティブと森林生態資源のセ ミドメスティケーション化」(小林繁男京都大学教授), 平成 24 年度総合地球環境学研究所資源領域プログラム 「砂漠化をめぐる風と人と土」(田中樹准教授）により実 施いたしました。本稿の執筆にあたっては, 京都大学の 大山修一先生, 査読者の方々をはじめとした多くの方々 から貴重なご意見をいただきました。この場を借りて， 心より感謝申し上げます。

\section{参考文献}

石本雄大 (2012)『サヘルに拈ける食料確保一旱魅や虫害への適 応拉よび対処行動一』京都大学アフリカ地域研究資料セン 夕一。

大山修一 (2010)「西アフリカ・サヘル帯における市場経済化の 発展と砂漠化問題」『人間環境論集』10: 13-34.

大山修一・近藤史・淡路和江・川西陽一 (2011)「ニジェール南 部におけるハウサの乾燥地農耕と耕作地の土地分類」『農耕 の技術と文化』27: 66-85.

平井將公 (2009)「西アフリカ・サバンナ帯の人口稠密地域にお ける生業変容と植生管理に関する研究—セネガルのセレール 社会を事例として」京都大学2009年度博士論文.

藤岡悠一郎 (2010)「変容するサバンナ地帯の降雨依存農業」篠 田雅人 · 門村 浩 - 山下博樹編『乾燥地の資源とその利用保
全』古今書院, pp.85-104.

Berkes, Fikret Colding, Johan and Folke Carl (2000) "Rediscovery of Traditional Ecological Knowledge as Adaptive Management," Ecological Applications 10: 1251-1262.

Bielders, Charles L., Rajot, Jean-Louis and Amadou, Moustapha (2002) "Transport of soil and nutrients by wind in bush fallow and traditionally managed cultivated field in the Sahel," Geoderma 109: 19-39.

Hayashi, Keiishi, Fashola, Oluwarotimi, O., Masunaga, Tsugiyuki, Wakatsuki, Toshiyuki (2000a) "Indigenous Soil Knowledge for Sustainable Agricultural Development in the Sahel Zone of Niger, West Africa 1. Soil Quality Characterization of a Small Inland Valley Watershed," Tropics 9: 245-258.

Ikazaki, Kenta, Shinjo, Hitoshi, Tanaka, Ueru, Tobita, Satoshi, Funakawa, Shinya and Kosaki, Takashi (2011) "“Fallow Band System," a land management practice for controlling desertification and improving crop production in the Sahel, West Africa 1. Effectiveness in desertification control and soil fertility improvement," Soil science and plant nutrition 57: 573-586.

Molagnoux, Michel, Sène, El, Hadji and Atzmon Nir (2007) "Forests, trees and water in arid lands: a delicate balance,"Unasylva 58: 2429.

Pearce, David (1988) "Natural resource management and antidesertification policy in the Sahel-Sudan zone: A case study of Gum Arabic," Geojournal 17: 349-355.

United Nations Environment Programme, ed. (1992) World atlas of desertification, New York, Edward Arnold.

Weber, Fred, R., Nolman, Frederick, J. and Palmer, Virginia C. (1983) Reforestation in Arid Lands, Appropriate Technologies for Development. Manual M-5, Washington D. C., Peace Corps.

Wezel, Alexander and Lykke, Anne, Mette (2006) "Woody vegetation changes in the Sahelian West Africa: evidence from local knowledge," Environment Development and Sustainability 8: 553-567. 


\title{
(Summary)
}

\section{Tree Shapes Classification and Multi-purpose Tree Use of Hausa Farmers in Sahel Region of Southern Niger}

\author{
Hitomi KIRIKOSHI \\ Graduate school of Asian and African Area Studies, Kyoto University / \\ Research Fellow of the Japan Society for the Promotion of Science
}

The land degradation (desertification) problem and drought brought about food shortages and malnutrition of the people in Sahel region, West Africa. This paper clarified their coping strategies for the ecological vulnerabilities by their local ecological knowledge of the tree species and shapes.

Hausa people recognize the tree shapes by eyesight and classify four categories of tree shapes: laubu, barau, matashi and mayanchi in Hausa language. $L a u b u$ indicates small saplings, younger than one year old without cutting lower branches. Barau is over two years old trees and farmers do not cut down nor pollard the branches. They regard small trees with the pollarded branches as matashi, and big-trunk trees higher than millets as mayanchi.

Laubu and barau are used for sand accumulation and prevention of land degradation. Matashi is intended for crop protection from wind and solar heat. Mayanchi provide shade for livestock and people, and mayanchi provide important people's food and livestock fodder. The farmers have ecological knowledge to manage the tree shapes and innovate tree use in their millet fields, by judging the soil condition and yield of their crop fields. 